\title{
Apparent digestibility of diets with different concentrations of lysine and energy in piglets with different body weights and post-weaning age ${ }^{1}$
}

\author{
Messias Alves da Trindade Neto ${ }^{2}$, Daniel Gonçalves Bruno ${ }^{3}$, Dirlei Antonio Berto ${ }^{4}$, Michael \\ Undi $^{5}$, Eliana Aparecida Schammass ${ }^{6}$
}

${ }^{1}$ Projeto financiado pela Fundação de Apoio à Pesquisa do Estado de Sao Paulo - FAPESP, Brasil.

2 Departmento de Produção e Nutrição Animal da FMVZ-USP, Brasil.

3 Programa de Pós-graduação do Departamento de Produção e Nutrição Animal da FMVZ - USP, Brasil.

${ }^{4}$ Departamento de Produção Animal, FMVZ, UNESP/Botucatu, SP, Brasil.

${ }^{5}$ Department of Animal Science, University of Manitoba, Winnipeg, Canada.

6 Instituto de Zootecnia, SSA-SP, Brasil.

ABSTRACT - The effects of body weight or age and dietary digestible lysine and metabolizable energy on apparent digestibility of energy and dry matter were evaluated in piglets after weaning. The animals were weaned at 21 days of age and distributed in two groups: $8.68 \pm 0.76 \mathrm{~kg}$ at 28 days of age (weaned 7 days earlier); and $12.73 \pm 0.99 \mathrm{~kg}$ at 35 days of age (weaned 14 days earlier). The pigs were allotted in digestibility cages in a completely randomized block design with the following factorial arrangements: $2 \times 4$ composed of two weight categories and four levels of digestible lysine $(1.222 ; 1.305 ; 1.390$ and $1.497 \%)$; and $2 \times 3$ composed of two weight categories and three levels of metabolizable energy (3,510; 3,700 and 3,830 kcal/kg rations). Digestible lysine was evaluated in six replications and metabolizable energy in eight replications and each animal constituted an experimental unit. Piglets with higher body weight and age were more efficient in nitrogen retention and energetic balance, compared to lighter and younger piglets, particularly those given lower concentration of lysine in the diet. The energy increase favored nitrogen retention by the heavier and older piglets. However, coefficients of dry matter and energy apparent digestibility did not differ among weight categories. Older and heavier piglets were more efficient in nitrogen retention, although this efficacy depended on concentration of the energy in the diet. This better use of protein and energy suggest differences on nutritional requirements.

Key Words: digestible amino acid, digestible energy, nitrogen retention, weaned

\section{Digestibilidade aparente de dietas com diferentes concentrações de lisina e energia, em leitões de diferentes pesos corporais e idade pós-desmame}

\footnotetext{
RESUMO - Os efeitos do peso corporal ou idade e da lisina digestível e energia metabolizável dietéticas sobre a digestibilidade aparente da energia e matéria seca, foram avaliados em leitões após o desmame. Os animais foram desmamados aos 21 dias de idade e distribuídos em dois grupos: 8,68 \pm 0,76 kg com 28 dias de idade (desmamados há sete dias); e 12,73 \pm 0,99 kg com 35 dias de idade (desmamados há 14 dias). Foram alocados em gaiolas de digestibilidade, em delineamento de blocos ao acaso nos esquemas fatoriais: $2 \times 4$ composto de duas categorias de peso e quatro níveis de lisina digestível $(1,222 ; 1,305 ; 1,390$; e 1,497\%); e $2 \times 3$ composto por duas categorias de peso e três níveis de energia metabolizável (3.510, 3.700 e $3.830 \mathrm{kcal} / \mathrm{kg}$ de ração). A lisina digestível foi avaliada em seis repetições e a energia metabolizável em oito repetições, considerando cada animal uma unidade experimental. Os leitões que apresentavam maior peso corporal e idade foram mais eficientes na retenção do nitrogênio e no balanço energético, comparados aos mais leves e mais novos, sobretudo os que receberam menor concentração de lisina na dieta. O aumento da energia favoreceu a retenção do nitrogênio pelos leitões mais pesados e mais velhos. Os coeficientes de digestibilidade aparente de matéria seca e energia, no entanto, não diferiram entre as categorias de peso. Os leitões mais velhos e com maior peso corporal são mais eficientes na retenção do nitrogênio, contudo essa eficácia dependeu da concentração de energia da dieta. Esse melhor aproveitamento da proteína e energia sugere diferenças nas exigências nutricionais.
}

Palavras-chave: aminoácido digestível, desmamados, energia digestível, retenção de nitrogênio 


\section{Introduction}

The low performance of piglets after weaning is partly caused by the poorly developed digestive system and the fact that it is not accustomed to dry food. The first two weeks after weaning are characterized as transitory phase for the piglet and it may be characterized by anorexic situations and damages on the production of digestive enzymes as well as on the intestinal villous. Under these circumstances, the diet digestibility and use of nutrients may change over time after weaning. On the other hand, feed composition and nutritional requirement tables do not consider this aspect.

Dietary ingredients with high digestibility and that are compatible with the piglet physiologic conditions require some considerations. The high inclusion of lactose source is a better alternative to substitute starch, whose use efficiency is lower in piglets due to its chemical complexity (Mahan \& Newton, 1993; Tokach et al., 1995). As observed by Barbosa et al. (1999); Soares et al. (2000) and Trindade Neto et al. (2002), the diet quality during the initial period of post-weaning may influence overall animal performance, with influences on weight and age at finishing phase.

The efficiency of piglet initial diet after weaning will depend, at some extent, on anatomical and physiological development of the gastrointestinal tract from the suckling phase (Owsley et al., 1986). At birth, the gastrointestinal system of the pig is immature and the changes in digestive enzyme secretions reflect on a fast increase of some nutrients digestibility. However, after weaning, very fast transformation occurs in the gastrointestinal tract, especially during the first week.

The changes in the piglet gastrointestinal tract after weaning are caused by the type of food and by postweaning transitory anorexia (Montagne et al., 2007). This anorexia affects digestive enzyme secretion (Marion et al., 2003) and intestinal villous size (Berto et al., 1996), however, the animal may have a fast recovery (Marion et al., 2003; McCracken, et al., 1999). Therefore, the digestibility and retention of some nutrients by the piglet may change from one week to another. Nevertheless, published nutritional tables do not specify the age and body weight of the animals used in determining the published values in the immediate post-weaning phase.

The objective this study was to determine the apparent digestibility of diets with variable concentrations of digestible lysine and metabolizable energy in piglets in the first weeks after weaning.

\section{Material and Methods}

Forty-eight castrated piglets, obtained from a commercial farm, were used in this trial. The piglets were divided into two groups of 24 per group based on age and weight. The first group was weaned one week earlier than the second group, thus at the start of the experiment, the first group weighed $12.73 \pm 0.99 \mathrm{~kg}$ and at the age of 35 days while the second group weighed $8.68 \pm 0.76 \mathrm{~kg}$ at 28 days of age. From weaning to start of the experimental adaptation, the piglets from the first group received the same diet (pre-initial phase). The piglets, housed in metabolism crates, were submitted to 13 days in evaluation period, during which seven were an adaptation period when feed was offered ad libitum. However, 24 hours before the collection period, all piglets were weighed to calculate metabolic weight $\left(\mathrm{BW}^{0.75}\right)$ and feed intakes during the collection period were based on metabolic weight as described by Matterson et al. (1965). Total fecal and urine collections were carried out in the last six days as described by Barbosa et al. (1985). Ferric oxide was used as fecal marker. Apparent digestibility of dry matter, nitrogen and energy were determined.

This study was designed as a follow-up to the study by Trindade Neto et al. (2009) in which the ratio between digestible lysine and metabolizable energy for nursery piglets $(6.90 \pm 1.11 \mathrm{~kg})$ was evaluated. The results of this study showed that increase in metabolizable energy resulted in a higher nitrogen retention, whereas increase in lysine reduced nitrogen retention. In the current study, four levels of digestible lysine (1.222; 1.305; 1.390 and $1.497 \%)$ and three levels of metabolizable energy (3510, 3700 and $3830 \mathrm{kcal} / \mathrm{kg}$ of food) were separetely evaluated at two body weight categories. Other nutritional requirements (Table 1) were formulated to meet minimal requirements as suggested by NRC (1998) and Rostagno et al. (2005).

The study was designed as a randomized block design with a factorial arrangement. Each pig was considered an experimental unit and initial weight was used to form the blocks. When digestible lysine was considered, the factorial scheme was $2 \times 4$ with six replications. When metabolizable energy was considered, the factorial scheme was $2 \times 3$ with eight replications. The body weights were the following: $12.73 \mathrm{~kg}$ (35 days of age) and 8.68 (28 days of age). The data was analyzed by using the GLM procedure of SAS (SAS, 2004).

\section{Results and Discussion}

During the experimental period, the room temperature ranged from $19.4 \pm 1.2^{\circ} \mathrm{C}$ to $25.2 \pm 1.0^{\circ} \mathrm{C}$. Due to the piglet 
weight or age effect on some studied variables, the results (Table 3) were presented according to two weight categories, under digestible lysine and metabolizable energy treatments.

The observed differences $(\mathrm{P}<0.01)$ on dry matter intake and excretion and energetic balance was followed by changes on piglets weight and it was expected that the heaviest and the most adapted animals had a greater feed intake. However, the relative values of metabolizable energy and energetic balance remained at the same percentage rates between the piglet categories.

The nutritional quality of diets, with around $15 \%$ lactose and a low inclusion of soybean meal, avoided damages on

Table 1 - Ingredient and nutrient composition of experimental diets

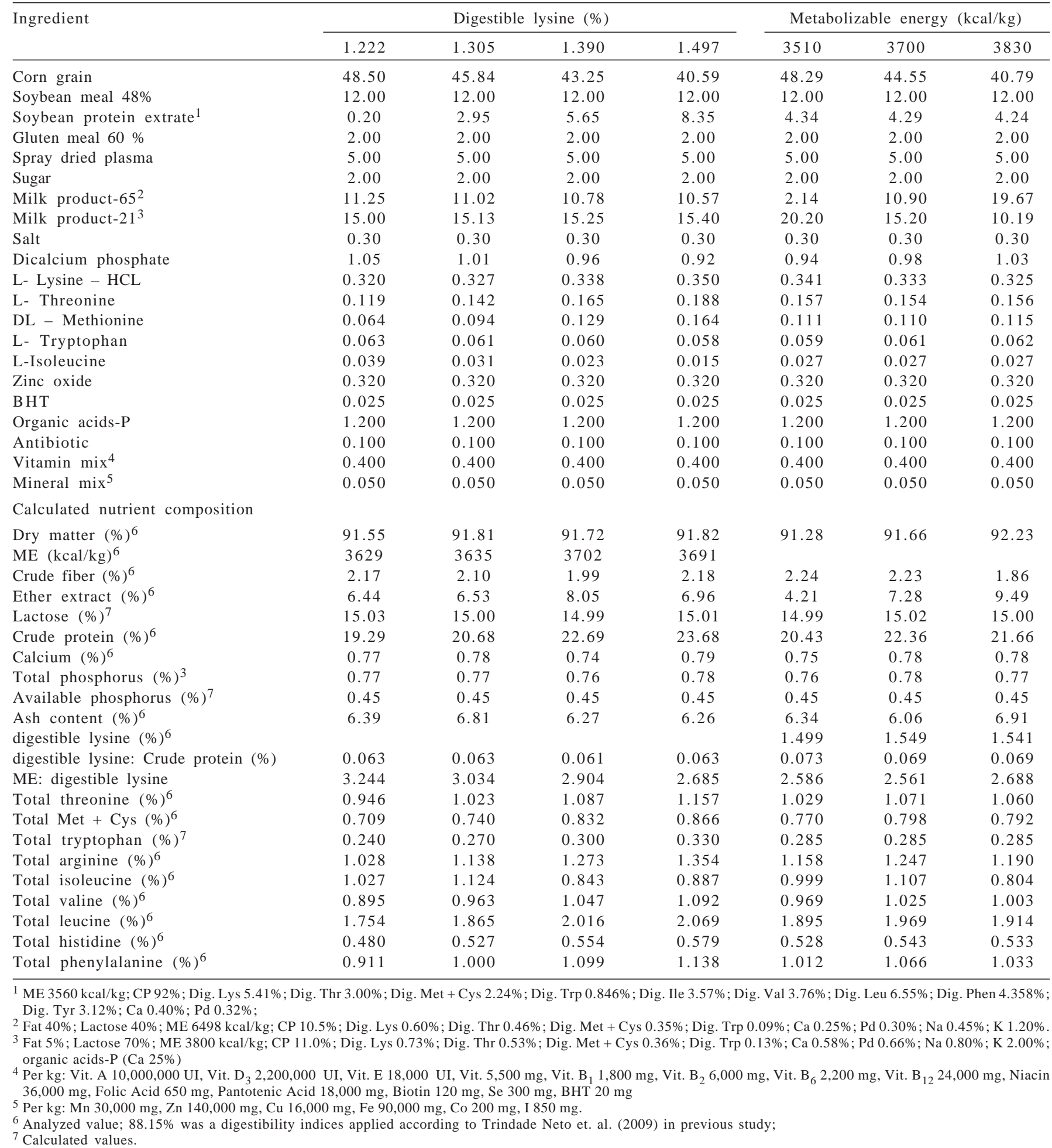


dry matter digestibility which did not affected by piglet body weight. Some studies in literature have focused on biological values of ingredients used in piglet diet formulations in the first two weeks after weaning, mainly when weaning age is reduced. In this case, under the early weaning, the piglet underwent abrupt interruption changes on social, environment, and dietary conditions. The strong nutritional change and all factors, at same time, coincide with low feed intake. From this short period and non adaptation arises an anorexia situation with alteration on intestinal mucosa integrity and on enzymatic secretion standard of pancreas (Vente-Spreeuwenberg et al., 2004). Therefore, this new situation for weaned piglet, from fasting or low feed intake, is considered a multi factorial effect. From a nutrition point of view, the limited luminal substrate flow, to supply the intestinal epithelium for cell growth, reduces the growing factor expression and the secretion from digestive organs as colecistokinine (Montagne et al., 2007), Glucagon-like peptide-2 (GLP-2) and Insulin-like growth factor 1 (IGF-1) (Stoll et al., 2000; Vente-Spreeuwenberg \& Beynen, 2003). After acute period of the digestive enzyme secretions decreasing (Marion et al, 2003) and intestinal villous damage (Berto et al., 1996), the small intestine maturation in relation the physiologic functions is followed (Boudry et al., 2004) when the piglet increase the feed intake and gradual recovery during the next successive days (Marion et al., 2003).

Some studies showed similar concern in piglet evaluations from 0 to 5 , from 6 to 15 and from 4 to 11 days after weaning (Montagne et al., 2007; Nabuurs et al., 1993; Hedemann \& Jensen, 2004, respectively).

In the current study, the physiological maturation stage on gastrointestinal tract response was characterized through the percentage of absorbed and retained nitrogen $(\mathrm{P}<0.05)$. The animals with at approximate weight of $13 \mathrm{~kg}$ were more efficient $(\mathrm{P}<0.05)$ on dietary protein use and they retained $(\mathrm{P}<0.02)$ higher quantity of nitrogen (Figure 1$)$ mainly in $1.222 \%$ digestible lysine concentration. This response coincided with a major metabolizable energy: digestible lysine (3.244 Mcal EM/\% digestible lysine) ratio. Other authors observed this major absorption of nitrogen compounds in function of the piglet physiologic maturity. Caine et al. (1997) observed amino acid digestibility from soybean meal-based diets, supplied to piglets was significantly lower from 6 to 7 days after weaning compared with days 15 to 16 after weaning.

The efficiency of nitrogen use was also characterized $(\mathrm{P}=0.06)$ according to dietary energy increase in heavier piglets. Dietary energy concentration is essential for this efficiency, particularly when the piglet is more adapted to digestion as occurred with animals at $13 \mathrm{~kg}$ body weight (Figure 2). Considerations about the pig physiologic state in these development phases are not sufficiently considered on food nutritional evaluations and current elaboration of food compounds table for swine.

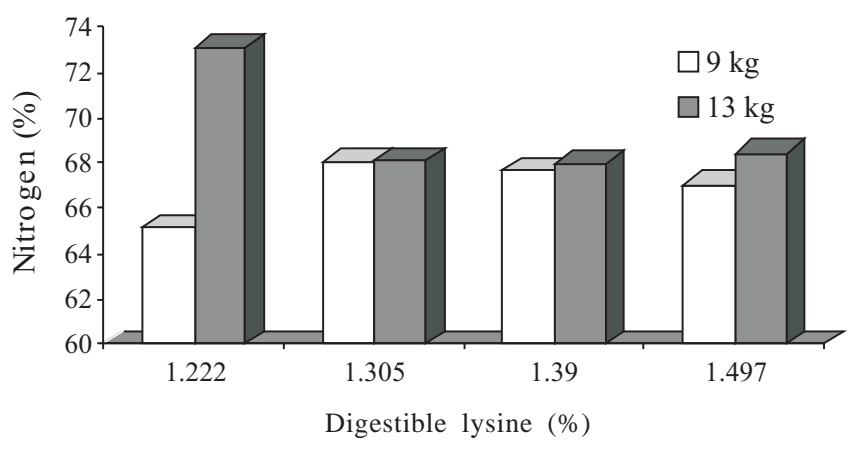

Figure 1 - Nitrogen retention in piglets, from two body weight category, feed with digestible lysine supplied diets

Table 2 - Analyzed amino acids composition of experimental diets used in digestibility assay ${ }^{2}$

\begin{tabular}{|c|c|c|c|c|c|c|c|}
\hline & \multicolumn{4}{|c|}{ Digestible lysine (\%) } & \multicolumn{3}{|c|}{ Metabolizable energy (kcal/kg) } \\
\hline & 1.222 & 1.305 & 1.390 & 1.497 & 3538 & 3636 & 3821 \\
\hline Total amino acid $^{1}$ & 1.387 & 1.481 & 1.577 & 1.698 & 1.463 & 1.549 & 1.541 \\
\hline Threonine & 0.946 & 1.023 & 1.087 & 1.157 & 1.029 & 1.071 & 1.060 \\
\hline Methionine & 0.366 & 0.390 & 0.448 & 0.480 & 0.413 & 0.429 & 0.421 \\
\hline Cysteine & 0.343 & 0.351 & 0.378 & 0.386 & 0.357 & 0.370 & 0.366 \\
\hline Methionine + Cysteine & 0.709 & 0.740 & 0.832 & 0.866 & 0.770 & 0.798 & 0.792 \\
\hline Arginine & 1.085 & 1.138 & 1.273 & 1.354 & 1.158 & 1.247 & 1.190 \\
\hline Isoleucine & 1.028 & 1.124 & 0.843 & 0.887 & 0.999 & 1.107 & 0.804 \\
\hline Valine & 0.895 & 0.963 & 1.047 & 1.082 & 0.969 & 1.025 & 1.003 \\
\hline Leucine & 1.754 & 1.865 & 2.016 & 2.069 & 1.895 & 1.969 & 1.914 \\
\hline Histidine & 0.480 & 0.527 & 0.554 & 0.579 & 0.528 & 0.543 & 0.533 \\
\hline Phenylalanine & 0.911 & 1.000 & 1.099 & 1.138 & 1.012 & 1.066 & 1.033 \\
\hline Alanine & 0.973 & 1.029 & 1.120 & 1.132 & 1.463 & 1.549 & 1.541 \\
\hline
\end{tabular}

1 Analyses conducted by Ajinomoto Biolatin-Brazil.

2 Dry matter content of samples $90 \%$. 
The case of nitrogen digestibility difference among animals at 9 and $13 \mathrm{~kg}$ in the present study could explain the observations by Montagne et al. (2007). The authors observed that from 0 to 5 days after weaning, there was a reduction on the intestinal villous high; on macromolecules flow through jejunum; and on the small intestine villous relative weight that decreased $18 \%$ from 0 to 2 days after weaning. According the authors, from 0 to 5 days after weaning animal showed a recovery which was characterized by increase of proximal jejunum mass followed by villous size increase.

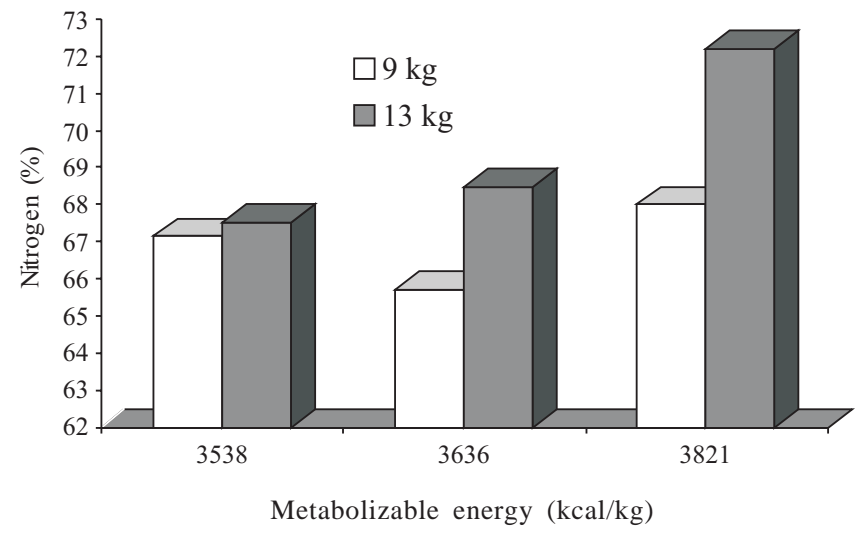

Figure 2 - Nitrogen retention in piglets, from two body weight category feed, with metabolizable energy supplied diets.
Vente-Spreeuwenberg et al. (2004) verified that piglets had lower villous high in proximal and medium portion of small intestine on 4 and 7 days after weaning compared to 0 day values, while on the $14^{\text {th }}$ day, again, the villous achieved similar height compared to previous values at weaning. Since the intestinal villous is responsible for the intestine structures by intestine nutrient absorptions, this study suggests that one factor that might have contributed to decrease the nitrogen absorption on younger piglet $(9 \mathrm{~kg})$ was the atrophy of these structures in this first phase after weaning.

Regarding enzymes responsible for protein digestion, Montagne et al. (2007) and Swenson \& Reece (1996) observed decrease in enzyme activity in the first week after weaning. Likewise, plasma concentration of colecistokinine, one of the factors responsible for pancreatic enzyme secretion (Swenson \& Reece, 1996), followed a similar pattern, decreasing from 0 to 5 days after weaning and increasing in the following week. These authors concluded that trypsin activity was associated with feed intake regained by piglets and its turn, by following time after the weaning.

Unlike nitrogen absorption, which was higher in $13 \mathrm{~kg}$ piglets, the digestible dry matter, digestible and metabolizable energy values were similar at both body weight categories. These results suggest similarity in digestion conditions for non-protein substrates such as carbohydrates and lipids, which are present in significant proportions in the diets offered to piglets. According to

Table 3 - Apparent digestibility of diets with different lysine and energy levels in piglets after weaned ${ }^{1}$

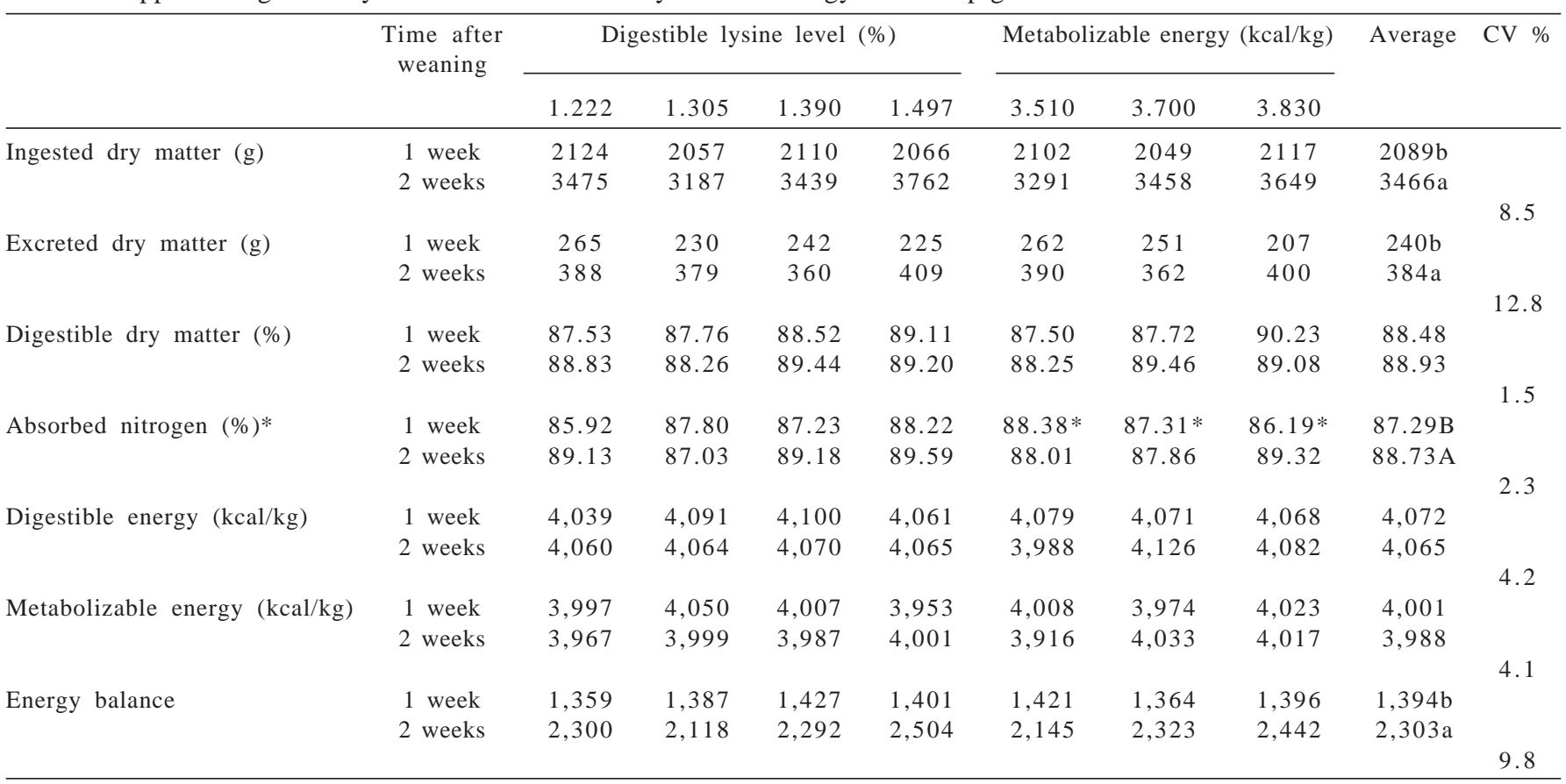

\footnotetext{
${ }^{1}$ Average followed by different letters in same column differ by test $\mathrm{F}$, capital $(\mathrm{P}<0.05)$ and small $(\mathrm{P}<0.01$. $)$
}

* Linear effect $(\mathrm{P}<0.05)$ for energy level on $9 \mathrm{~kg}$ piglet category. 
Huguet et al. (2006), the activities of pancreatic amylase and lipase moderately increase after weaning. In weaned piglets at 28 days of age, Hedemann \& Jensen (2004) suggested reduced pancreatic amylase activity on the first 5 days. On the other hand, the specific activity of lipase falls to $79 \%$ after weaning and remains low during the recovery period, but reverse occurs with trypsin as observed Marion et al (2003) and Montagne et al. (2007) from the $5^{\text {th }}$ to $15^{\text {th }}$ day after weaning. Regarded to similarity among digestible and metabolizable energy in animals ranging from 9 and $13 \mathrm{~kg}$, the weaning age effect may have some influence on physiological conditions, associated with digestion.

\section{Conclusions}

For castrated male piglets weaned at 21 days of age, body weight and time after weaning are important determinants of nitrogen absorption efficiency, although, the characteristics of dietary protein substrates are significant too. Older and heavier piglets are most efficient in nitrogen retention; however, this efficacy depends on dietary energy concentration. This better use of protein and energy indicates differences on the nutritional requirements in piglets of different ages.

\section{References}

BARBOSA, H.P.; PEREIRA, J.A.A.; COSTA, P.M.A. et al. Exigência de proteína bruta para leitões na fase inicial de crescimento ( 5 a $15 \mathrm{~kg}$ de peso). Revista Brasileira de Zootecnia, v.14, n.1, p.45-52, 1985.

BARBOSA, H.P.; TRINDADE NETO, M.A.; SORDI, I.M P. Efeitos dos processamentos do milho comum e da soja integral no desempenho de leitões desmamados aos 21 dias de idade. Boletim da Indústria Animal, v.56, n.1, p.59-66, 1999.

BATTISTI, J.A.; PEREIRA, J.A.A.; COSTA, P.M.A. et al. Composição química e valores energéticos de alguns alimentos para suínos com diferentes idades. Revista Brasileira de Zootecnia, v.14, n.2, p.141-180, 1985.

BERTO, D.A.; KRONKA, R.N.; DOS SANTOS, H.S.L. et al. Efeitos das dietas iniciais na morfologia e digestibilidade de nutrientes em leitões desmamados. Revista Brasileira de Zootecnia, v.25, n.5, p.973-986, 1996.

BOUDRY, G.; PERON, V.; LE HUEROU-LURON, I. et al. Weaning induces both transient and long-lasting modifications of absorptive, secretory, and barrier properties of piglet intestine. Journal of Nutrition, v.134, n.9, p.2256-2262, 2004.

CAINE, W.R.; SAUER, W.C.; TAMMINGA, S.; et al. Apparent ileal digestibilities of amino acids in newly weaned piglets fed diets with protease-treated soybean meal. Journal of Animal Science, v.75, p.2962-2969, 1997.

DUNSHEA, F.R.; KERTON, D.K.; CRANWELL, P.D. et al. Lifetime and post-weaning determinants of performance indices of pigs. Australian Journal of Agricultural Research, v.54, p.363-370, 2003.

HEDEMANN, M.S.; JENSEN, B.B. Variations in enzyme activity in stomach and pancreatic tissue and digesta in piglets around weaning. Archives of Animal Nutrition, v.58, n.1, p.47-59, 2004.

HUGUET, A.; SAVARY, G.; BOBILLIER, E. et al. Effects of level of feed intake on pancreatic exocrine secretions during the early postweaning period in piglets. Journal of Animal Science, v.84, n.11, p.2965-2972, 2006.

MAHAN, D.C.; NEWTON, E.A. Evaluation of feed grains with dried skim milk and added carbohydrate sources on wealing pig performance. Journal Animal Science, v.71, n.12, p.3376-3382, 1993.

MARION, J.; ROME, V.; SAVARY, G. et al. Weaning and feed intake alter pancreatic enzyme activities and corresponding mRNA levels in 7-d-old piglets. Journal of Nutrition, v.133, n.2, p.362-368, 2003.

MATTERSON, L.D.; POTTER, L.M.; STUTZ, N.W. et al.. The metabolizable energy of feed ingredients for chikens. Storrs: Connecticut University, Agricultural Experiment station. 1965. 11p. (Research report).

MCCRACKEN, B.A.; SPURLOCK, M.E.; ROOS, M.A. et al. Weaning anorexia may contribute to local inflammation in the piglet small intestine. Journal of Nutrition, v.129, n.3, p.613-619, 1999.

MONTAGNE, L.; BOUNDRY, G.; FAVIER, C. et al. Main intestinal markers associated with the changes in gut architecture and function in piglets after weaning. British Journal of Nutrition, v.97, n.1, p. 45-57, 2007.

NABUURS, M.J.A.; HOOGENDOORN, A.; VAN DER MOLEN, E.J. et al. Villus height and crypt depth in weaned and unweaned pigs, reared under various circumstances in the Netherlands. Research in Veterinary Science, v.55, p.78-84, 1993.

OWSLEY, W.F.; ORR, D.E.; TRIBBLE, L.F. Effects of age and diet on the development of the pâncreas and the synthesis and secretion of pancreatic enzymes in the young pig. Journal of Animal Science, v.63, n.2, p.497-504, 1986.

PLUSKE, J.R.; KERTON, D.K.; CRANWELL, P.D. et al. Age, sex, and weight at weaning influence organ weight and gastrointestinal development of weanling pigs. Australian Journal of Agricultural Research, v.54, n.5, p.515-527, 2003.

ROSTAGNO, H.S.; ALBINO, L.F.T.; DONZELE, J.L. et al Composição de alimentos e exigências nutricionais. (Tabelas brasileiras para aves e suínos). Viçosa, MG: UFV, 2005. 186p.

SOARES, J.L.; DONZELE, J.L.; OLIVEIRA, R.F.M. et al. Soja integral processada (fermentada e extrusada) e farelo de soja em substituição ao leite em pó em dietas de leitões desmamados aos 14 dias de idade. Revista Brasileira de Zootecnia, v.29, n.4, p.1153-1161, 2000.

STATISTICAL ANALYSES SYSTEM - SAS. User's guide: statistics. 12.ed. New York: SCOTT, M.L. \& Associates. 2004. $1686 \mathrm{p}$.

STOLL, B.X.; CHANG, X.; FAN, M.Z. et al. Enteral nutrient intake determines the rate of intestinal protein synthesis and accretion in neonatal pigs. The American Journal of Physiology, v.279, p.49-57, 2000.

SWENSON, M.J.; REECE, W.O. Dukes fisiologia dos animais domésticos. 11.ed. Rio de Janeiro: Guanabara Koogan, 1996. $856 \mathrm{p}$.

TOKACH, M.D.; PETTIGREW, J.E.; JOHNSTON, L.J. et al. Effect of adding fat and (or) milk products to the weaning pig diet on performance in nursery and subsequent grow-finishing stages. Journal of Animal Science, v.73, n.11, p.3358-3368, 1995.

TRINDADE NETO, M.A.; BARBOSA, H.P.; PETELINCAR, I.M. et al. Dietas para leitões nas fases de creche e diferentes idades ao desmame. Revista Brasileira de Zootecnia, v.31, n.2, p.672-680, 2002.

TRINDADE NETO, M.A.; BERTO, D.A.; ALBUQUERQUE, R. et al. Relação lisina digestível e energia metabolizável para leitões em 
fase pré-inicial de creche. Revista Brasileira de Zootecnia, v.38, n.7, p.1291-1300, 2009.

VENTE-SPREEUWENBERG, M.A.M.; BEYNEN, A.C. Dietmediated modulation of small intestinal integrity in weaned piglets. In: PLUSKE, J.R.; LE DIVIDICH, J.; VERSTEGEN, M.W.A. (Eds.) Weaning the pig, concepts and consequences. Wageningen: Wageningen Academic Publisher, 2003. p.145-199.

VENTE-SPREEUWENBERG, M.A.M.; VERDONK, J.M.A.J.; BAKKER, G.C.M. et al. Effect of dietary protein source on feed intake and small intestinal morphology in newly weaned piglets. Livestock Production Science, v.86, n.1-3, p.169-177, 2004. 